\title{
The Causes of Lack of Pharmaceutical Logistics Monitoring in Surgery Rooms: A Case Study in a Type C Hospital
}

\section{Penyebab Kurangnya Monitoring Logistik Farmasi di Kamar Operasi: Studi Kasus pada Rumah Sakit Tipe C}

\author{
Luh Putu API', Abdi Agus Y, Wiwin Indriani ${ }^{2}$ \\ ${ }^{1}$ Hospital Management Master Degree Program Faculty of Medicine Universitas Brawijaya Malang \\ ${ }^{2}$ Rumah Sakit Bhayangkara Hasta Brata Batu
}

\begin{abstract}
The surgery rooms have an important role in the hospital, so it must be managed properly. The surgery rooms consume $9 \%$ of the annual hospital budget. High operational costs caused by the large cost of human resources, medical materials, and other supporting facilities. This study was conducted in a private hospital type $C$ with 181 beds and has four surgery rooms. The number of patients which was operated in X Hospital was very high, and the highest number in July 2019 reached 515 patients. There were a large supply of drugs and medical devices in the surgery rooms. The number of each drug reached hundreds ampoule, and medical devices reached tens and some in the hundreds. The management of pharmaceutical supplies in the surgery rooms was carried out by senior nurse head of surgery rooms. Monitoring logistic by pharmacy officer only done once a month. This made excessive of stock and become expired. The purpose of this study was to analyze the factors that cause the lack of pharmaceutical logistics monitoring in the surgery rooms. Determination the root of the problem was done by using a fishbone diagram through a Focus Group Discussion with the division heads and subdivision heads of X Hospital. Focus Group Discussion is done by asking the participants one by one to find the root of the problem based on five factors (man, material, method, machine, and environment). Obtained 8 root problems then analyzed with 5 why to get the main root problem. Furthermore, determine the biggest problem using the CARL (capability, accessibility, readiness, and leverage) method, with a weighting score between 1-5. The results found that the absence of pharmaceutical logistics monitoring SOP in the surgery rooms was the most contributing factor to the lack of pharmaceutical logistics monitoring in the surgery rooms.
\end{abstract}

Keywords: Logistics, monitoring, pharmacy, surgery rooms

\begin{abstract}
ABSTRAK
Kamar operasi memiliki peran penting di rumah sakit, sehingga harus dikelola dengan baik. Kamar operasi menghabiskan 9\% dari anggaran tahunan rumah sakit. Biaya operasional yang tinggi disebabkan oleh besarnya biaya sumber daya manusia, bahan medis, dan fasilitas pendukung lainnya. Penelitian ini dilakukan di rumah sakit swasta tipe C dengan 181 tempat tidur dan memiliki empat kamar operasi. Jumlah pasien operasi di Rumah Sakit tempat studi sangat tinggi, dengan jumlah tertinggi pada Juli 2019 sebanyak 515 pasien. Jumlah persediaan untuk setiap obat di kamar operasi mencapai ratusan ampul, dan alat kesehatan mencapai puluhan dan beberapa mencapai ratusan. Pengelolaan logistik kamar operasi setiap harinya dilakukan oleh perawat senior yaitu kepala kamar operasi. Pemantauan oleh petugas farmasi hanya dilakukan sebulan sekali. Hal ini membuat jumlah stok berlebihan dan mendekati expired. Tujuan dari penelitian ini adalah untuk menganalisis faktor-faktor yang menyebabkan kurangnya pengawasan logistik farmasi di kamar operasi. Penentuan akar masalah dilakukan dengan menggunakan diagram tulang ikan dan 5 why, dan penentuan prioritas akar masalahan menggunakan metode CARL. Analisis dilakukan melalui Focus Group Discussion kepala divisi dan kepala subdivisi Rumah Sakit X. Focus Group Discussion dilakukan dengan bartanya satu per satu pada peserta untuk mencari akar masalah berdasarkan 5 faktor (man, material, method, machine, and environment). Diperoleh 8 akar masalah kemudian dianalisis dengan 5 why untuk mendapatkan akar masalah utama yang akan dianalisis menggunakan metode CARL (capability, accessibility, readiness, and leverage), dengan skor bobot antara 1-5. Hasil penelitian menemukan bahwa tidak adanya SOP pemantauan logistik farmasi di kamar operasi adalah faktor yang paling berkontribusi terhadap kurangnya pemantauan logistik farmasi di kamar operasi.
\end{abstract}

Kata Kunci: Farmasi, kamar operasi, logistik, monitoring

Correspondence: Luh Putu API. Hospital Management Master Degree Program Faculty of Medicine Universitas Brawijaya Malang Faculty of Medicine Universitas Brawijaya Malang, Jl. Veteran Malang Tel.085745457609 Email: ayoe.iswari@gmail.com 


\section{INTRODUCTION}

Hospital is a health service organization that provides medical and support services (1). One of the crucial services in the hospital is the surgery rooms which costs $9 \%$ of the annual hospital budget. The biggest expenditure in hospitals from the activities in the surgery rooms, which was about $40 \%$ from $70 \%$ of total hospital cost (2). Hospital management must be able to guarantee the quality of services provided to patients in accordance with the minimum service standards set by the government (3). The high operating costs are due to a large number of resources used including human resources, consumables, and other supporting facilities. Research stated the central surgical installation is one of the hospital units that functions as the second largest income unit after the pharmacy installation. The cost of pharmaceutical supplies in a central surgical installation ranks second largest after services so that if efficiency efforts can be made it will be very meaningful to reduce the operational costs of the central surgical installation (4). Another research supported that Operating Room (OR) generally holds both high volume and high cost. Without an efficient procedure to ensure the operating room runs lean, the probability of costs associated with waste occurring is extremely high (5). Therefore the hospital must carry out cost efficiency so that the service can continue to run optimally (2).

This study was conducted is a type $C$ private hospital with 181 beds and has four surgery rooms $(6,7)$. The hospital has outpatient, inpatient, intensive care, surgery rooms, and support services. At present, the hospital has obtained plenary accreditation status with a priority service in the surgical services. As a priority service, the performance of surgical services is measured by the number of patients who undergo operation that is shown reached the highest in July as many as 515 patients (7). The high number of surgery patients must match the availability of human resources and logistics supplies that must be managed in a structured manner. In accordance with the regulation concerning hospitals, the management of pharmaceutical preparations in hospitals is the responsibility of the pharmaceutical installation (8). The selection of pharmaceutical logistics in the surgery rooms of this Hospital follows the hospital's formulary and considers the users' suggestion and is compared with the prices listed in the e-catalog of pharmaceutical service standards in X Hospital (9).

Pharmacy logistics management is very important for hospitals because pharmacy supplies that are too large or too small will be make a loss for the hospital (10). From the observations, the logistics stock in the surgery rooms were shown by medical devices such as surgical needle the number for each type reached six to eight boxes, and other medical devices reached tens. The number for narcotics and psychotropic drugs that reached more than 50 ampoules and non-narcotics drugs reaches more than 100 ampoules. From the observation found that there were several drugs and medical devices close to expire. Also not all stock card filled, some of them were not filled for more than 1 year. This may happen because of monitoring activities carried by pharmaceutical officers was only done once a month. The lack of periodical monitoring may lead to damage and expire stock. Research that high drug turnover rates require a good logistics management, monitoring, and inventory management system. It is intended that the logistics inventory is secured from the risk of loss and damage. Thus a good pharmaceutical stock monitoring can improve efficiency and minimize errors and damage that can harm the patient (11).

The high amount of surgery rooms inventory can affect the effectiveness and cost-efficiency of the hospital. Excessive inventory is one of the eight potential wastes in hospitals (2). Too many amount of inventory effects on the higher hospital expenses that should be suppressed through efficiency in logistics planning. Another study stated that the placement of pharmaceutical depots and pharmacy officers during working hours affects the stock conformity with formulary standards, minimizing losses, and could save costs through reducing unnecessary drugs and product optimization (12). Unfortunately, the pharmaceutical logistics monitoring system in the surgery rooms has not yet been implemented at this hospital. Therefore, this study aims to explore the factors that influence the implementation of pharmaceutical logistics monitoring in surgery rooms in a Hospital.

\section{METHOD}

This research was a descriptive study that aims to explore the factors that cause the lack of pharmaceutical logistics monitoring in the surgery rooms. The study began with the identification of problems which was conducted using field observation, interviews, hospital data, literature studies, and Focus Group Discussions (FGD). The first FGD was conducted on September 23, 2019 and was attended by middle officials, namely the head of the division and young officials who were the heads of the sub-division with a total of fifteen participants. First FGD was done by asking the participants one by one to find the root of the problem in the logistics of the surgery rooms using fishbone diagram based on five factors (man, material, method, machine, and environment). Obtained 8 root problems which are then analyzed with 5 why to get the main root problem. The second FGD was conducted on October 42019 was attended by middle officials, namely the head of the division and young officials who were the heads of the subdivision with a total of nine participants, to assess the main root of the problem with the highest risk that had to be solved first using CARL (capability, accessibility, readiness, and leverage) method. The weighting score between 1-5 through filling the scoring sheet. Furthermore, the scoring sheets collected are calculated to determine the highest score.

\section{RESULT}

The first FGD conducted to find the root cause of the lack of pharmaceutical logistics monitoring in the surgery rooms using fishbone diagram based on five factors, there were man, material, method, machine, and environment factor (Figure 1). The results show that in the man factor, the pharmacists and pharmaceutical technical staff who have not carried out routine logistics monitoring including in the surgery rooms and the nurses who have not routinely recorded consumable medical materials used during surgery. In the method factor, some of the procedures performed were not following the Standard Operating Procedures (SOP) such as request for logistic from the surgery rooms to the pharmacy through WhatsApp 


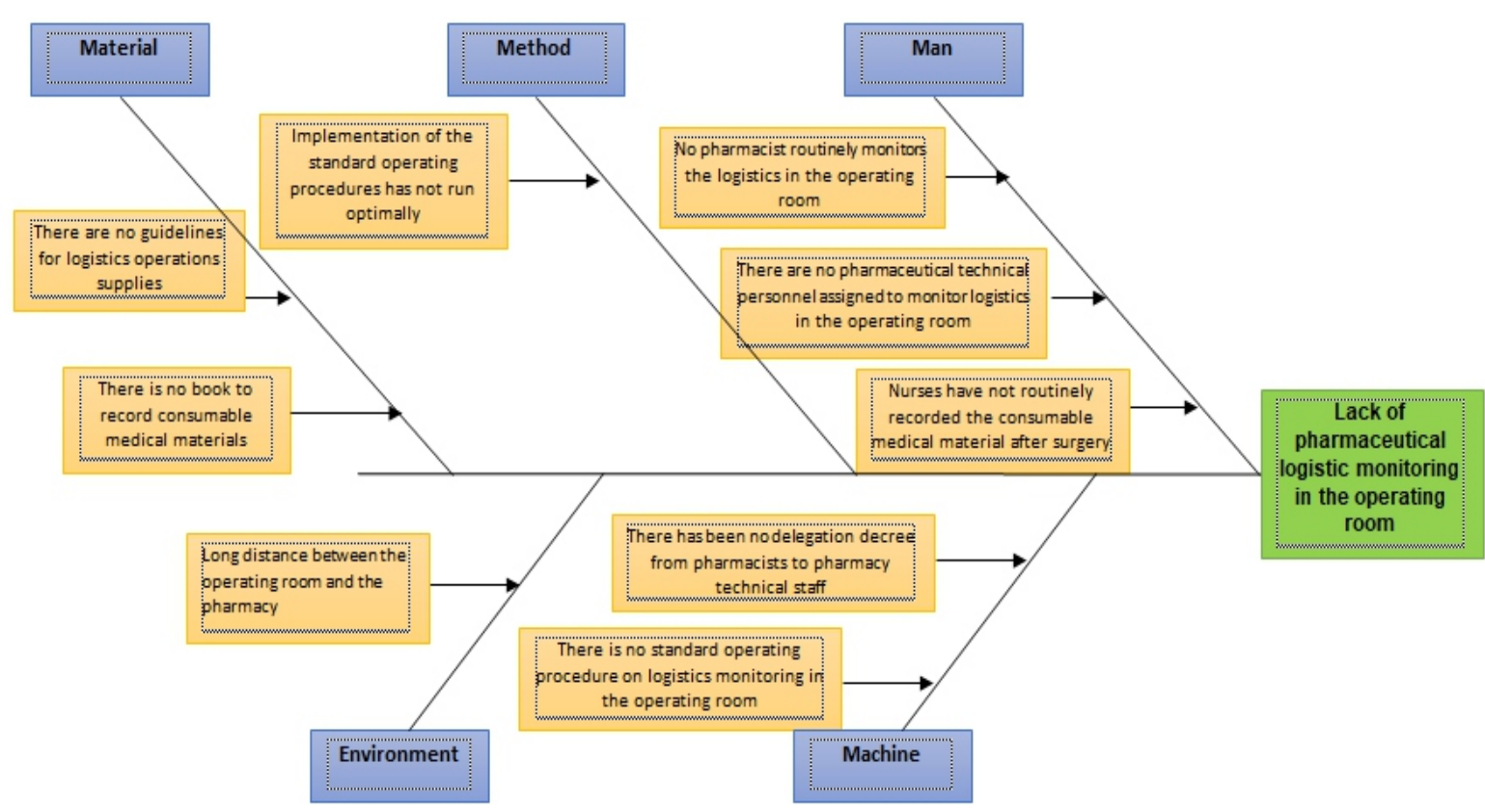

Figure 1 Fishbone Diagram of lack of pharmaceutical logistic monitoring in the Surgery rooms

application which should be use a letter of request. In the material factor, no structured logistical supplies guidelines in the surgery rooms, and no media for nurses to record consumable medical materials used during surgery. Further in the machine factor, the hospital has not yet determined any letter of delegation from pharmacists to pharmaceutical technical personnel for logistics monitoring in the surgery rooms, and no SOP for logistics monitoring flow in the surgery rooms. Also the long distance between the surgery rooms and pharmacy installation hinder the implementation of logistics monitoring.

Based on the problems identified using fishbone, root problem analysis was performed using 5 why analysis (Table 1). The eight root causes identified served as the basis for determining the root cause priorities. In the man factor, there has been no monitoring and evaluation of the duties and authority of the pharmacist, the delegation letter has not been made from pharmacist to pharmaceutical technical personnel and no person in charge to records consumable medical materials after surgery during the shift. In the machine factor, guideline for supervision of pharmaceutical technical personnel has not been made and a culture of monitoring and evaluation has not yet formed. In material factor, the absence of SOP for logistics monitoring in the surgery rooms, and guidelines are not yet made for logistics supplies in the surgery rooms. In the method factor, there has been no socialization, monitoring, and evaluation on the standard operating procedures. In the environment factor, the schedule for pharmacy officers who are on standby in the surgery rooms has not yet been made.

Table 1. Analysis of root problems using 5 why

\begin{tabular}{|c|c|c|c|c|c|c|}
\hline No & Component & Problem & Why & Why & Why & Why \\
\hline \multirow[t]{3}{*}{1} & Man & $\begin{array}{l}\text { No pharmacist } \\
\text { routinely monitors } \\
\text { the logistics in the } \\
\text { surgery rooms }\end{array}$ & $\begin{array}{l}\text { The pharmacist } \\
\text { delegates to the } \\
\text { head of the } \\
\text { surgery rooms }\end{array}$ & $\begin{array}{l}\text { Lack of pharmacists } \\
\text { in the hospitals } \\
\text { therefore the } \\
\text { pharmacist need to } \\
\text { work in other units }\end{array}$ & $\begin{array}{l}\text { There were no clear } \\
\text { duty and authority } \\
\text { for pharmacists }\end{array}$ & $\begin{array}{l}\text { There has been } \\
\text { no monitoring } \\
\text { and evaluation of } \\
\text { the duties and } \\
\text { authority of the } \\
\text { pharmacist }\end{array}$ \\
\hline & & $\begin{array}{l}\text { There are no } \\
\text { pharmaceutical } \\
\text { technical } \\
\text { personnel } \\
\text { assigned to } \\
\text { monitor logistics } \\
\text { in the surgery } \\
\text { rooms }\end{array}$ & $\begin{array}{l}\text { There were no } \\
\text { rules for routine } \\
\text { monitoring of } \\
\text { logistics in the } \\
\text { surgery rooms }\end{array}$ & $\begin{array}{l}\text { There were no } \\
\text { delegation letter } \\
\text { from pharmacist to } \\
\text { pharmaceutical } \\
\text { technical personnel } \\
\text { to carry out routine } \\
\text { monitoring of } \\
\text { logistics in the } \\
\text { surgery rooms }\end{array}$ & $\begin{array}{l}\text { The delegation } \\
\text { letter has not been } \\
\text { made from } \\
\text { pharmacist to } \\
\text { pharmaceutical } \\
\text { technical personnel }\end{array}$ & \\
\hline & & $\begin{array}{l}\text { Nurses have not } \\
\text { routinely recorded } \\
\text { the consumable } \\
\text { medical material } \\
\text { after surgery }\end{array}$ & $\begin{array}{l}\text { Nurses do not } \\
\text { have the } \\
\text { awareness to take } \\
\text { notes }\end{array}$ & $\begin{array}{l}\text { There is no } \\
\text { responsible person } \\
\text { to record the } \\
\text { consumable medical } \\
\text { materials during } \\
\text { shift }\end{array}$ & $\begin{array}{l}\text { No person in charge } \\
\text { to records } \\
\text { consumable medical } \\
\text { materials after } \\
\text { surgery during the } \\
\text { shift }\end{array}$ & \\
\hline
\end{tabular}


Table 1. Analysis of root problems using 5 why (Lanjutan)

\begin{tabular}{|c|c|c|c|c|c|c|}
\hline No & Component & Problem & Why & Why & Why & Why \\
\hline \multirow[t]{2}{*}{2} & Machine & $\begin{array}{l}\text { There has been no } \\
\text { delegation decree } \\
\text { from pharmacists } \\
\text { to pharmacy } \\
\text { technical staff }\end{array}$ & $\begin{array}{l}\text { No delegation } \\
\text { decree has been } \\
\text { made from } \\
\text { pharmacists to } \\
\text { pharmaceutical } \\
\text { technical staff }\end{array}$ & $\begin{array}{l}\text { Supervision of } \\
\text { pharmaceutical } \\
\text { technical personnel } \\
\text { has not been carried } \\
\text { out }\end{array}$ & $\begin{array}{l}\text { Guideline for } \\
\text { supervision of } \\
\text { pharmaceutical } \\
\text { technical personnel } \\
\text { have not been made }\end{array}$ & \\
\hline & & $\begin{array}{l}\text { There is no } \\
\text { standard } \\
\text { operating } \\
\text { procedure on } \\
\text { logistics } \\
\text { monitoring in the } \\
\text { surgery rooms }\end{array}$ & $\begin{array}{l}\text { Standard } \\
\text { operating } \\
\text { procedure for } \\
\text { monitoring in the } \\
\text { surgery rooms is } \\
\text { not yet made }\end{array}$ & $\begin{array}{l}\text { There are no } \\
\text { significant problems } \\
\text { with logistics in the } \\
\text { surgery rooms }\end{array}$ & $\begin{array}{l}\text { A culture of } \\
\text { monitoring and } \\
\text { evaluation has not } \\
\text { yet formed }\end{array}$ & \\
\hline \multirow[t]{2}{*}{3} & Material & $\begin{array}{l}\text { There are no } \\
\text { guidelines for } \\
\text { logistics } \\
\text { operations } \\
\text { supplies }\end{array}$ & $\begin{array}{l}\text { There is no } \\
\text { method to } \\
\text { calculate logistical } \\
\text { needs in the } \\
\text { surgery rooms }\end{array}$ & $\begin{array}{l}\text { Calculation was } \\
\text { based on average } \\
\text { needs }\end{array}$ & $\begin{array}{l}\text { There is no } \\
\text { definitive guideline } \\
\text { for calculating } \\
\text { logistical needs in } \\
\text { the surgery rooms }\end{array}$ & $\begin{array}{l}\text { There was no SOP } \\
\text { for logistics } \\
\text { monitoring in the } \\
\text { surgery rooms }\end{array}$ \\
\hline & & $\begin{array}{l}\text { There is no book } \\
\text { to record } \\
\text { consumable } \\
\text { medical materials }\end{array}$ & $\begin{array}{l}\text { There are no } \\
\text { technical } \\
\text { guidelines for } \\
\text { recording } \\
\text { consumable } \\
\text { medical materials }\end{array}$ & $\begin{array}{l}\text { Guidelines are not } \\
\text { yet made for } \\
\text { logistics supplies in } \\
\text { the surgery rooms }\end{array}$ & & \\
\hline 4 & Method & $\begin{array}{l}\text { Implementation } \\
\text { of the standard } \\
\text { operating } \\
\text { procedures has } \\
\text { not run optimally }\end{array}$ & $\begin{array}{l}\text { Standard } \\
\text { operating } \\
\text { procedures are } \\
\text { not routinely } \\
\text { done }\end{array}$ & $\begin{array}{l}\text { Lack of awareness in } \\
\text { following the } \\
\text { standard operating } \\
\text { procedures }\end{array}$ & $\begin{array}{l}\text { There has been no } \\
\text { socialization, } \\
\text { monitoring, and } \\
\text { evaluation on the } \\
\text { standard operating } \\
\text { procedures }\end{array}$ & \\
\hline 5 & Environment & $\begin{array}{l}\text { The distance } \\
\text { between the } \\
\text { surgery rooms and } \\
\text { the pharmacy is } \\
\text { quite far }\end{array}$ & $\begin{array}{l}\text { There is no } \\
\text { pharmacy depot } \\
\text { in the surgery } \\
\text { rooms }\end{array}$ & $\begin{array}{l}\text { There are no } \\
\text { pharmacists on } \\
\text { standby in the } \\
\text { surgery rooms }\end{array}$ & $\begin{array}{l}\text { The schedule for } \\
\text { pharmacy officers } \\
\text { who are on standby } \\
\text { in the surgery } \\
\text { rooms has not yet } \\
\text { been made }\end{array}$ & \\
\hline
\end{tabular}

From the first FGD obtained 8 root problems then further analyzed with 5 why to get the main root problem. The second FGD was to assess the main root of the problem with the highest risk that had to be solved first using CARL criteria. Scoring was obtained by filling out check sheets obtained from 9 respondents who attend during the second FGD. The weighting score between 1-5 through filling the scoring sheet. Furthermore, the scoring sheets collected are calculated to determine the highest score. The results of the analysis identified three priority issues, the first there has been no socialization, monitoring, and evaluation of pharmaceutical logistics SOP in the surgery rooms, the second there was no SOP of logistics monitoring flow in the surgery rooms, and the third no person in charge records consumable medical materials after surgery during the shift (Table 2).

Table 2. Results of root priority scoring results using CARL

\begin{tabular}{lllc}
\hline No & \multicolumn{1}{c}{ Problem list } & Total & Rank \\
\hline $\mathbf{1}$ & $\begin{array}{l}\text { There has been no socialization, } \\
\text { monitoring, and evaluation of } \\
\text { pharmaceutical SOP in the surgery } \\
\text { rooms }\end{array}$ & 2916 & 1 \\
$\mathbf{2} \quad \begin{array}{l}\text { There was no SOP for logistics } \\
\text { monitoring in the surgery rooms }\end{array}$ & 2771 & 2 \\
\hline
\end{tabular}

Table 2. Results of root priority scoring results using CARL

\begin{tabular}{|c|c|c|c|}
\hline No & Problem list & Total & Rank \\
\hline 3 & $\begin{array}{l}\text { No person in charge records } \\
\text { consumable medical materials } \\
\text { after surgery during the shift }\end{array}$ & 2318 & 3 \\
\hline 4 & $\begin{array}{l}\text { Guidelines are not yet made for } \\
\text { logistics supplies in the surgery } \\
\text { rooms }\end{array}$ & 2024 & 4 \\
\hline 5 & $\begin{array}{l}\text { The delegation letter has not been } \\
\text { made from pharmacist to } \\
\text { pharmaceutical technical } \\
\text { personnel }\end{array}$ & 1934 & 5 \\
\hline 6 & $\begin{array}{l}\text { There has been no monitoring and } \\
\text { evaluation of the duties and } \\
\text { authority of the pharmacist }\end{array}$ & 1282 & 6 \\
\hline 7 & $\begin{array}{l}\text { Guideline for supervision of } \\
\text { pharmaceutical technical } \\
\text { personnel have not been made }\end{array}$ & 1008 & 7 \\
\hline 8 & $\begin{array}{l}\text { The schedule for pharmacy officers } \\
\text { who are on standby in the surgery } \\
\text { rooms has not yet been made }\end{array}$ & 913 & 8 \\
\hline
\end{tabular}

\section{DISCUSSION}

This study identified three priority root causes that hampered the implementation of the logistics monitoring system in the surgery rooms. Because of socialization, monitoring, and evaluation of pharmaceutical SOP in the 
surgery rooms was part of the SOP logistic in the surgery rooms, the root cause of the first problem became the absence of SOP on monitoring logistic in surgery rooms, the second problem the absence of socialization, monitoring, and evaluation of SOP, and third problem no person in charge records consumable medical materials in surgery rooms.

The first root problem was the absence of SOP of the pharmaceutical logistics monitoring flow in surgery rooms. Based on the hospital pharmacy organizing guideline, logistics in the surgery rooms is the responsibility of the pharmaceutical installation (13). Monitoring of pharmaceutical supplies stored in the surgery rooms is done by monitoring using stock cards for narcotics and psychotropic drugs as well as monthly stock conducted by the pharmaceutical installation and surgery rooms staff (14). The observations showed that the monitoring using card stock has not been running optimally. There were stock cards that haven't been filled for more than a year. The existing SOP was only about the logistics demand flow from surgery rooms to the pharmaceutical installation. Research stated that the existence of SOP can make employees work according to their duties and authority appropriately so that it affects the performance results. Employees can also save time and work effectively and efficiently because there are clear references. In addition, employees understand their duties and responsibilities because there are clear references because the SOP has described each employee's job description (15).

The second problem was the absence of socialization, monitoring, and evaluation of pharmaceutical logistics SOP in the surgery rooms. So far, pharmaceutical supplies in the surgery rooms have only been carried out by the head of the surgery rooms who was a senior nurse, along with the recovery room nurses to carry out prescription handover with inpatient pharmacists. In addition, procedures were still found mismatched with the SOP, one of which was the request for logistic from the surgery rooms to the pharmacy through WhatsApp application which should be use a letter of request. This is due to the absence of re-socialization, monitoring, and evaluation of SOP which is worsened by the lack of awareness of officers to carry out procedures according to SOP. Research the implementation of the SPO socialization seen from the pre and post socialization, obtained an increase of $25 \%$ the number of compliance rate in surgery rooms staff who arrived on time (16). These findings are consistent with the results of research found that the factors that influence nurses' compliance in the implementation of SOP are nurses' motivation and perceptions of their work. Nurse's perceptions of their work influence nurses' compliance with SOP implementation compared to nurses' motivation (17).

\section{REFERENCES}

1. Kussuma MA. Rancangan Model Manajemen Persediaan Obat Kategori AV dengan Analisis ABC (Pareto) dan Klasifikasi VEN pada Instalasi Farmasi Rumah Sakit Bedah Surabaya. [Thesis]. Universitas Airlangga, Surabaya. 2017.

2. Yudiansyah AG, Yuliansyah N, and Pitoyo AZ. Peningkatan Efektifitas dan Efisiensi Perbekalan
The third root is that there is no person in charge to record medical consumables after surgery during the shift also plays an important role in the logistics monitoring process in the surgery rooms. The surgery rooms does not yet have an SOP which contains a description of the duties and authority of the pharmacy officer who monitors the logistics in the surgery rooms, as well as a description of the duties and authority for nurses in the surgery rooms who are in charge recording consumable medical materials in the surgery rooms. The absence of clear job descriptions and authority is a factor influencing the work motivation of officers. Officers perceive that recording medical consumables is not a mandatory thing to be done because there are no written regulations so that the recording is not carried out properly. The job description and authority of the person responsible for recording medical consumables have not been written in the organization guidelines.

Another factor that might influence work motivation in recording is gender. The majority of nurses in the surgery rooms are male. Research found that in the central surgical installation where the majority of nurses were male, organizational commitment is lacking, especially administrative matters in the form of recording and reporting (4). This is also supported by research that states gender can also affect a person's level of motivation and compliance. Women are more likely to be obedient in carrying out work than men, even though this difference is small (18). From these studies it can be seen that gender has an important role in motivation and compliance at work. Female staffs tend to be more obedient at work than male even though there was little difference. Overall, the absence of SOP on logistics monitoring in the surgery rooms as well as the officers in accordance with their authority are the root of the problems of implementing logistics monitoring in the surgery rooms in the hospital where this study was carried out. The hospital needs to develop an SOP on logistics monitoring in the surgery rooms that includes the logistics planning flow, monitoring, and evaluation, as well as the division of tasks and authority for the related staff.

From this study it was found that the root cause of the lack of pharmaceutical logistics monitoring in surgery rooms of the studied hospital caused by three main root problems that had to be resolved. First problem there were no SOP for logistics monitoring in the surgery rooms. The second problems there were no socialization, monitoring, and evaluation of pharmaceutical SOP in the surgery rooms. The third problem there was no person in charge records consumable medical materials after surgery during the shift. This study can provide benefits for hospitals to find out the problems that occur in the hospital, look for the root cause of the problem, so it is useful in determining alternative solutions to problems and improve the quality of hospital services.

Farmasi di Instalasi Kamar Operasi RSIG. Jurnal Ilmiah Kesehatan Rustida. 2018; 5(2): 627-633.

3. Dampung V, Maidin A, and Mardiana R. Penerapan Metode Konsumsi dengan Peramalan, EOQ, MMSL dan Analisis ABC-VEN dalam Manajemen Perbekalan Farmasi di Rumah Sakit Pelamonia Makassar. Media Farmasi. 2018; 14(1): 97-104.

4. Sa'adah E, Andadari N, and Kurniawati J. Faktor yang 
Mempengaruhi Efisiensi Perbekalan Farmasi di Instalasi Bedah Sentral Rumah Sakit Umum Daerah Gambiran Kediri. Jurnal Kedokteran Brawijaya. 2014; 28(1): 15-20.

5. Schmidt RN, Posteraro RH, and Lopez M. Reducing Waste in the Operating Room Through InventoryBased Supply Chain Optimization. Journal of Bussiness and Behavioral Sciences. 2019; 31(1): 74-84.

6. Rumah Sakit Gatoel. Pelayanan Profesional Sepenuh Hati. (Internet) 2019. http://rsgatoel.co.id/ [accessed October 2, 2019].

7. Rumah Sakit Gatoel. Laporan Kerja Kamar Operasi. Mojokerto; Rumah Sakit Gatoel: 2019.

8. Menteri Hukum dan Hak Asasi Manusia Republik Indonesia. Undang-Undang Republik Indonesia No. 44 Tahun 2009 tentang Rumah Sakit. Jakarta: Kementerian Hukum dan Hak Asasi Manusia RI; 2009; p. 12.

9. Malinggas NER, Posangi J, and Soleman T. Analisis Manajemen Logistik Obat di Instalasi Farmasi Rumah Sakit Daerah Dr Sam Ratulangi Tondano. Jurnal Ilmu Kesehatan Masyarakat Unsrat. 2015; 5(2): 448-460.

10. Amanda El. Evaluasi Pelaksanaan Sistem dan Prosedur Akuntansi Persediaan Obat-obatan. [Skripsi]. Universitas Pembangunan Nasional "Veteran", Surabaya. 2011.

11. Herliantine $S$ and Chalidyanto D. Pengelolaan Sediaan Obat Pada Logistik farmasi Rumah Sakit
Umum Tipe B di Jawa Timur. Jurnal Administrasi Kesehatan Indonesia. 2016; 4: 136-145.

12. Thomas JA, Martin V, and Frank S. Improving Pharmacy Supply-Chain Management in the Operating Room. Healthcare Financial Management. 2000; 54(12): 58-61.

13. Youandi AA. Pedoman Pengorganisasian Farmasi 2019. Indonesia; XX-SURKP/RSG/18.063-82, 2018. p. 27-8.

14. Youandi AA. Pedoman Pelayanan Instalasi Farmasi 2019. Indonesia; 2018. p. 51-2.

15. Sudarmo S, Helmi ZN, and Marlinae L. Faktor yang Mempengaruhi Perilaku terhadap Kepatuhan Penggunaan Alat Pelindung Diri (APD) Untuk Pencegahan Penyakit Akibat Kerja. Jurnal berkala Kesehatan. 2016; 1(2): 88-95.

16. Aweq FL, Ifantono N, and Hakim L. Efektifitas Standar Prosedur Operasional terhadap Penurunan Waktu Tunggu Operasi Elektif di Rumah Sakit Umum. Jurnal Medicoeticolegal dan Manajemen Rumah Sakit. 2017; 6(2): 158-162.

17. Nazvia, Loekqijana A, and Kurniawati J. Faktor yang Mempengaruhi Kepatuhan Pelaksanaan SOP Asuhan Keperawatan di ICU-ICCU RSUD Gambiran Kota Kediri. Jurnal Kedokteran Brawijaya. 2014; 28(1): $21-25$.

18. Agustini T and Mulya CA. Hubungan Motivasi Kerja dan Imbalan yang di Terima Perawat dalam Kepatuhan Pendokumentasian Flowsheet. Jurnal Ilmiah Kesehatan Pencerah. 2019; 8(1): 67-74. 